\title{
Advantages and Disadvantages of Student Loans Repayment Patterns
}

\author{
Hua Shen (Corresponding author) \\ Faculty of Education, Hubei University \\ 11 Xueyuan Street, Wuhan 430062, China \\ E-mail: shenhua1997@163.com
}

The research is financed by Ford Foundation. No. (1075-0792) (Sub-program Sponsoring)

\begin{abstract}
It is a difficulty problem to choice repayment patterns of student loan. "Conventional mortgage-type loan" and "Income contingent loan" has been performed in many countries. These loan repayment manners have their own characteristics. In this paper, we discuss their advantages and disadvantages, and would provide policy choice for student loans programs in China. These suggestions maybe supply references to other developing countries.
\end{abstract}

Keywords: Student loans, Conventional mortgage-type loan (CML), Income contingent loan (ICL)

\section{Introduction}

There are many patterns of the student loans repayment, for example, the "Conventional Mortgage-type loan (CML)", "Income contingent loan (ICL)", graduates tax, employer tax, social pension, national forgiveness and so on. The CML and ICL are mostly performed right now. Many economists, policy makers and aid office staffs discussed the pros and cons of these two kinds of loan repayments. Different countries choose different repayment manner to improve their student loan efficiency.

In this paper, besides the first part, it includes the following parts: the second part discusses the CML repayment manner; the third analysis the ICL repayment pattern; the last part, according to the student loan situation in China, gives some suggestion for policy.

\section{Conventional mortgage-type loan (CML) repayment pattern}

The Conventional Mortgage-type student loan has been most commonly adopted by many countries. This repayment manner is one of the commercial loan which is called amortization. Its main feature is that during the loan periods the borrower pays off the loan all the principal and interest according to a certain interval. Each paying amount is fixed in every certain time point.

\subsection{The CLM repayment condition}

In many countries or regions, they have adopted the "traditional mortgage-type" student loan repayment program to specify the installment method. Amortization condition includes interest rate, repayment period, repayment frequency, each repayment amount and so on (See Table 1).

Interest rate is the ratio of the lending amount to the repayment amount, and it is often regulated by lending interest rates of commercial bank, inflation rates or consumer price index etc. In many countries, governments usually support interest subsidies for student loans programs. For example, during the study and the grace period, the interest is exempted, or only considering the inflation, the real interest rate is zero or a fixed rate.

Usually total repayment periods include a grace period, repayment period and extend period. The grace period is the interval from graduation to the first repayment beginning time. Its role is to postpone the first repayment, to provide students with job gaps, thus reduced the initial debt burden. Repayment period is the length of time which the borrowers pay off all principal and interest. The extended period is provided to the borrower who could not fully repay the loan on time and requests to the bank for extending the loan term.

The forms of conventional mortgage-type loans are also diversified. Some loans of repayment frequency are monthly, quarterly or annual installments equal payments. Such as the Government Subsidized Student Loan (GSSL) is the quarterly repayment in China. Some student loans are graduated repayment installments which the amount of each repayment increased from $1.5 \%$ in the first year and gradually added for the last $13.0 \%$ during 15 years such as in Thailand (Ziderman, 2003).

In general, repayment conditions are diversified in student loan program, and it also reflects the student loan characteristics in different countries. 


\subsection{The CML advantages}

\subsubsection{Borrower preknowing the certain paying point of time, interest and amount}

The biggest advantage of amortization method is that borrowers could precisely calculate the repayment capital and interest according to their loan amount and interest rates, so that the graduates clearly know their loans debt burden. In order to avoid loans default, students could determine their own amount of loans. For example, the Direct Student Loan Program in the United States, assuming that student borrows $\$ 5,000$ U.S. dollars, according to the contract his repayment periods are 10 years, so he should repay monthly $\$ 61$ and the total principal and interest of $\$ 7,395$. At the same time, graduates are also clearly aware of their principal and interest repaid each time point, it can reduce the repayment default caused by their memory errors.

\subsubsection{Lender preknowing the collect amount}

The lenders as well as could calculate and preknow how much they collect, in order to determine invest the project funds in the next year. It makes the student loan program become the real "opened loan fund" not "unlimited capital investment". For example, the Student Loan Scholarship in Japan, the ratio of the amount of annual reimbursement loan to the lending increased from 15.6 percent in 1981 to 26.8 percent in 1985, and to 42.6 percent in 1994(Zhao,1996). In 2006, the recovery proportion of two categories student loan further enhanced. In the Student Loan Scholarship of the first category, the loan repayment amount is 1.718 billion yen, accounting for 63.1 percent in the lending amount. From the overall perspective, the rate of the repayment to the total investment is 29.42 percent (Shibata Masayuki, 2006). After several years of operation, student loan funds could in theory achieve self-sufficiency.

\subsubsection{No need for private income track and collection}

Graduate repayment amount is fixed, and is not relationship to graduates future income. There is no need exactly to track and calculate the private income, which can significantly reduce student loans management costs.

View of the above advantages, Professor Johnston and Professor Adrian Ziderman recommend to adopt the CML in developing countries. Professor Johnstone said "More important, a conventional loan with a lower present value of repayments is still fundamentally less expensive to repay, and therefore arguably "better" for the student borrower, than an income contingent loan with a high interest rate and a high present value of the total expected repayment stream, even if the income contingent loan may seem more 'manageable'." (Johnstone, 2000) Apart from the above advantages, there are also many disadvantages of the CML which could not be overcome by themselves.

\subsection{The CML disadvantages}

\subsubsection{CML not general availability}

The loan eligibility needs to be determined before loan disbursement. Means-test is the most useful method to investigate the economic situation of student family. Knowing the household income of loan applicants is an arduous and difficult work. The deviation of household income survey will result in poor student difficult to obtain loans. On the contrary, students from wealthy families enjoy the loan assistant.

\subsubsection{Repayment amount not correspond to graduate income}

The each repayment amount of amortization is fixed and unchanging, so the graduate debt burden is contrary with the expected revenues. This repayment method is not sensitive with the graduate future income. With the increasing of working years, the borrower income will be enhanced. However, at an early working stage student personal income is relatively low and his debt burden is high incurred loan Therefore, amortization incurred high risk loan arrears and defaults.

\subsubsection{Defaulter credit record be hurt}

In the case of financial credit system maturing, the graduate appears student loan default, and it will directly affect the borrower's credit rating and credit records, such as housing loans and other consumer goods may be blocked. In addition, since poor students fear of loan defaults, they may abandon the student loan application, then ultimately impact on higher education accessibility.

As the CLM have some shortcomings and disadvantages. In 1989, a complete new student loan pattern happened in Austria, and the Australian government performed the Higher Education Contribution Scheme (HECS). Now we introduce the income contingent student loan repayment pattern.

\section{Income contingent loan (ICL) repayment pattern}

\subsection{The ICL repayment condition}

Income contingent loan is "the collection of the debt depends on the borrowers' future levels of income"(Chapman, 2005). It includes ICL with Risk-Pooling, ICL with Risk-Sharing, Graduate Taxes and Human Capital Contract (Chapman, 2005). These repayment patterns supply brand-new approach for the student loan. 
The ICL repayment condition generally includes the repayment ratio which is the rate of each repayment amount to the income in correspond period, the income repayment threshold and the longest repayment periods (See Table 2). The repayment ratio is the main factor in the ICL, so the different student loan programs have the different repayment ratio. Such as the HECS is from 3 to 6 percent, and the student loan in New Zealand is the 10 percent of the total income minus the 15,492 NZD. Some countries have the longest repayment periods which are about 20 years. After the longest repayment periods, the loan could be forgiveness.

\subsection{The ICL advantages}

At first, the ICL is universal acquirable. The income contingent loan needs not means-test, there is no applicant eligible. Student could apply this loan according to their study fee. So there is not the applicant identification qualified, many students could obtain the loan.

Secondly, no repayment delinquencies and default take place. The ICL repayment amount is the proportion of the graduates future expected income, and just only the earning is more than the minimum income criteria, they will start their loan repayment. This does not occur repayment defaults and arrears, nor hurt the borrower's credit reputation. So it avoids the loan reverse selection and moral hazard. It is the most predominance of the ICL

Thirdly, the ICL have the high collecting efficiency through effective loan management institution. The ICL repayment amount based on the graduate expected income, so high income person could quickly pay off in the short term. At the same time, the government authorized tax institutions, pension insurance institutions and other related departments directly to deduct loan from personal income. So it saves the management costs and increases the efficiency of the loan collection.

\subsection{The ICL disadvantages}

Like a coin, everything has its two sides. The ICL also have its shortcomings. Now we discuss the disadvantages of the ICL.

Firstly, it is very difficulty to track the personal precise income in long-term. To determine the individual income is a difficult task, in the absence of effective mechanisms for income reporting and tax conditions, especially in developing countries. At the same time, it is also tight to determine the borrower repayment ratio, whether the income is pre-tax or after-tax. In addition, the low-income graduate repayment periods will normally be 20 years or longer, so loans last their lifetime or even several decades.

Secondly, an efficient loan management and recovery institutions should be matched to the ICL. Implementation of this student loan manner, the loan recovery is usually done by specialized agencies. For example, the Higher Education Contribution Scheme (HECS) in Austria, the universities should provide students with the tax numbers and specific amount of the loan to the tax system of Internal Revenue Department. In Ghana, the social pension insurance fund collects loans. In contrast, in Ethiopia, since the lack of a comprehensive income tax collection agencies and awareness of loan repayment, loan collecting still dependents on the government, so student loans face abortion in Ethiopia (Johnstone \& Aemero, 2001).

Thirdly, the repayment amount calculation is complex very much. Since personal income changing with the working experience and the environment factors, the repayment proportion will increase with income enhancing, and they will result in the difference of each repayment amount. The calculation of the repayment amount has become more complex than the amortization method which is fixed. Particularly in developing countries or economic transition states, the source of income is diversified and fluctuant, it makes difficult to accurately calculate and estimate the amount.

The last is that the recovery lost is difficult to be detected by financial institution. The low-income borrowers have the relative long repayment periods, especially their incomes below the repayment threshold, they need not pay off. So the financial institution could not find the loan loss in short-term.

\section{Policy Suggestions on the Student Loans in China}

\subsection{Refine the CML repayment conditions}

Since the repayment condition is diversified in different countries, the Government Subsidized Student Loan (GSSL) in China could refine the repayment conditions, such as reducing interest and extending repayment periods in order to alleviate debt burden. Financial institution and higher education institution should help students to improve the awareness of paying off the loan, to perform credit reputation education and to prevent loan default.

\subsection{Innovate the ICL repayment pattern}

There is only CLM manner in China, aiming at the disadvantages of the CLM, we should induct the ICL pattern. According to our survey, graduates have the doughty desire which is using ICL to repayment student loan. If we perform the ICL pattern for unemployed and low-income graduates, it could boost up their repayment trust and facilitate the student loan development. 


\subsection{Structure the high efficiency and specialization collecting institution}

Tax department or social security bureau participate in collecting student loan in order to save the management cost. We could make some experiments in a few of industries, for example government institution, foreign capital enterprise and so on which have the intact income records. Let the graduate choose the repayment manner ICL or CLM. In addition, we could structure the specialization collecting companies for student loan, and invest the student loan to second financial market, then allure more institutions and enterprises to invest student loan.

There is no panacea in the world, each repayment pattern has its advantages and disadvantages. economist Woodhall said that "in choosing between the various options, the planner must take account of : the costs to government of alternative rates of interest subsidy, the burden of debt facing borrowers, and the likely rate of default if repayment terms are too harsh" (Woodhall, 1987). So the repayment manner choice should according to its state conditions, not blindly copy and follow other countries, or else it will result in the irreparable damage, and even lead to the failure of student loan scheme.

\section{References}

Anashvili, V. V. (2006). Student loans analytical report. Conference on student loans in Russia, Ditchley Park, Oxfordshire, UK, January 27-29.

Chapman, B. (2005). Income contingent loans for higher education: International reform. Centre for economic policy research, Research school of social sciences, the Australian National University, Discussion paper No. 491. Canberra.

Chung, Y.P. and Hung, F.S. (2003). Student loans in Hong Kong: a perspective of loans agency. Journal of Higher Education, 24(1), 45-52 (in Chinese).

Federal Student Aid. (2006). The Guide to Federal Student Aid 2006-2007: Funding Education Beyond High School. Washington DC: US Governmen.

Information for Commonwealth supported students 2006, Australian Government Department of Education, Science and Training.

Inland Revenue. (2006). Making repayments, Student loans August 2006. IR 224.

Johnstone, D.B. (2000). Student loans in international comparative perspective: promises and failures, myths and partial Truths. Buffalo, NY: University at Buffalo Center for Comparative and Global Studies in Education. http://www.gse.buffalo.edu/org/IntHigherEdFinance/.

Johnstone, D.B. and Aemero, A. (2001). The applicability for developing countries of income contingent loans or graduate taxes, with special consideration of an Australian HECS-Type income contingent loan program for Ethiopia. Buffalo, NY: University at Buffalo Center for Comparative and Global Studies in Education http://www.gse.buffalo.edu/org/IntHigherEdFinance/.

Pillay, P. (2006). Student loan schemes in higher education: the South African experience. International symposium on student loan policy: a higher education financing policy to support the accumulation of human capital, BITEC, Bangkok, 15-16 March 2006.

Shibata Masayuki. (2006). Student financial aid policy in Japan. The International Symposium, Worldwide perspectives of financial assistance policy, December 6-7, Tokyo.

SSNIT. (2006). Loan disbursement and repayment. http://www.ssnit.com/corp_n.cfm?CorpID=5.

Usher, A. (2005). Global debt pattern: An international comparison of student loan burdens and repayment condition. Toronto: Educational Policy Institute.

Vossensteyn, H. (2004). Student financial support: An inventory in 24 European countries. Enschede, the Netherlands: Centre for Higher Educational Policy Studies (CHEPS).

World Bank. (2003). Higher Education Development for Ethiopia: Pursuing the Vision. World Bank.

Woodhall M. (1987) Lending for learning: Designing a student loan programme for developing countries. Commonwealth Secretariat.

Zhao Zhongjian. (1996). Student loan in university: international comparative research. Sichuan Educational Publish. Chengdu.

Ziderman, A. (2003). Student loans in Thailand: are they effective, equitable, sustainable? International Institute for Educational Planning. Paris: UNESCO.

Ziderman, A. (2004). Policy options for student loan schemes: lessons from five Asian case studies. International Institute for Educational Planning. Paris: UNESCO. 
Table 1. The CML repayment conditions international comparison

\begin{tabular}{|c|c|c|c|c|}
\hline Countries & $\begin{array}{l}\text { Interest } \\
\text { during study } \\
(\%)\end{array}$ & $\begin{array}{l}\text { Interest } \\
\text { during repayment } \\
(\%)\end{array}$ & $\begin{array}{l}\text { Grace periods } \\
\text { (month) }\end{array}$ & $\begin{array}{l}\text { Repayment periods } \\
\text { (year) }\end{array}$ \\
\hline Germany & 0 & 0 & 60 & 20 \\
\hline Russia & 22 & 22 & 12 & 10 \\
\hline China(Campus) & 0 & 6.12 & $0-24$ & 6 \\
\hline China(Local) & 0 & 6.12 & $0-24$ & 10 \\
\hline Hongkong (LSFS) & 2.5 & 2.5 & 5 & 5 \\
\hline Hongkong (NLS) & 4.625 & 4.625 & 10 & 10 \\
\hline Japan - category 1 & 0 & 0 & 0 & 20 \\
\hline Japan - category 2 & 0 & 3.0 & 0 & 20 \\
\hline Canada & 0 & 6.75 & 6 & 10 \\
\hline USA - SDSL & 0 & 3.37 & 6 & 10 \\
\hline USA-UDSL & 3.37 & 3.37 & 6 & 10 \\
\hline Egypt & 0 & 0 & 0 & 40 \\
\hline Namibia & 13.8 & 13.8 & 0 & 3 \\
\hline
\end{tabular}

Sourse: Vossensteyn, 2004; Anashvili, 2006; Ziderman, 2004; Chung\&Hung, 2003; Shibata Masayuki, 2006; Usher, 2005; Federal Student Aid, 2006

Table 2. The ICL repayment conditions international comparison

\begin{tabular}{l|l|l|l|l}
\hline Countries & $\begin{array}{l}\text { Interest } \\
(\%)\end{array}$ & $\begin{array}{l}\text { Repayment periods } \\
(\text { year })\end{array}$ & $\begin{array}{l}\text { Repayment } \\
\text { threshold }\end{array}$ & $\begin{array}{l}\text { Ratio } \\
(\%)\end{array}$ \\
\hline Australia & Inflate rate & - & 36,185 AUD & $4-8$ \\
\hline New Zealand & $0($ after 2007) & - & 17,160 NZD & 10 \\
\hline Stanford loan in USA & 8.25 & 25 & $\$ 25,000$ & 6.48 \\
\hline Sweden & 3.1 & 25 & - & 5 \\
\hline Ghana & 3 & 10 & - & 17.5 \\
\hline England \& Wales & 2.7 & 25 & £15,000 & 9 \\
\hline Ethiopia & 4 & 15 & - & 10 \\
\hline South Africa & 8.2 & - & 26,300 SFD & $3-8$ \\
\hline
\end{tabular}

Source: Information for Commonwealth supported students, 2006; Inland Revenue, 2006; Federal Student Aid, 2006; Usher, 2005; SSNNIT, 2006; World Bank, 2003; Pillay, 2006 